\title{
Effect of zinc-solubilizing bacteria and organic acids on zinc uptake and growth of rice applied with zinc sulfate
}

\author{
${ }^{1, *}$ Nur Maizatul Idayu, O., ${ }^{2}$ Radziah, O. And ${ }^{3}$ Halimi, M.S. \\ ${ }^{1}$ Faculty of Plantation and Agrotechnology, Universiti Teknologi Mara, Kampus Jasin, 77300, Jasin, \\ Melaka, Malaysia \\ ${ }^{2}$ Department of Land Management, Universiti Putra Malaysia, 43400 Serdang, Selangor, Malaysia \\ ${ }^{3}$ Department of Agriculture Technology, Universiti Putra Malaysia, 43400 Serdang, Selangor, Malaysia
}

\author{
Article history: \\ Received: 22 July 2020 \\ Received in revised form: 3 \\ December 220 \\ Accepted: 26 December 2020 \\ Available Online: 31 \\ December 2020
}

\section{Keywords:}

Zinc-solubilizing bacteria,

Organic acid,

Rice,

Zinc Sulfate

DOI:

https://doi.org/10.26656/fr.2017.4(S5).009

\begin{abstract}
An investigation on the influence of zinc-solubilizing bacteria (ZSB) inoculation, Zn fertilizer and organic acids on growth of rice was done at Microbiology lab, Universiti Putra Malaysia. Commercial oxalic acid (BDH), malic acid (SIGMA), citric acid (SIGMA), succinic acid (SIGMA) was used to solubilise $\mathrm{Zn}$ oxide, $\mathrm{Zn}$ carbonate and $\mathrm{Zn}$ sulfate at four different rates $(0,0.1,1.0$ and $10 \mathrm{mM})$. Selected organic acid and its rate was then combined with ZSB and $\mathrm{Zn}$ sulfate using sand culture experiment for rice plant treatment. Highest $\mathrm{Zn}$ sulfate solubilisation activity at $0.421 \mathrm{mg} / \mathrm{L}$ was found using citric acid as a solubilizer. Similar observation found for malic acid and oxalic acid in $\mathrm{Zn}$ sulfate at $0.331 \mathrm{mg} / \mathrm{L}$ and $0.249 \mathrm{mg} / \mathrm{L}$ respectively. Then, selected organic acids were malic acid and citric acid for plant treatment with $\mathrm{Zn}$-solubilizing bacteria (ZSB) and $\mathrm{Zn}$ sulfate. Highest plant biomass was found in inoculated plants treated with $0.1 \mathrm{mM}$ malic acid in the presence of $\mathrm{Zn}$ sulfate at $135.67 \mathrm{mg} / 3$ plants. The same treatment was also observed for the highest plant height at $29.57 \mathrm{~cm}$. With the addition of malic acid, the population of the rhizosphere, endosphere and non-rhizosphere varied, but higher than control treatment Application of ZSB inoculation, with $\mathrm{Zn}$ sulfate at $0.2 \mathrm{mg} / \mathrm{L}$ worked best with malic acid at $0.1 \mathrm{mM}$ concentration due to high increase of rice plant growth parameters, $\mathrm{Zn}$ uptake and $\mathrm{Zn}$ concentration. Bacterial populations also varied due to different organic acids and their rate.
\end{abstract}

\section{Introduction}

Organic acids have good potential to solubilise $\mathrm{Zn}$ because both proton and ligand-mediated mechanisms of mobilization play an integral role in the chemical attack on mineral's surface (Fomina et al., 2005). Plant roots release organic acids into the rhizosphere. Some of these organic acids like citric acid and malic acid are intermediates in the tricarboxylic (TCA) cycle for energy production while malic acid, malonate acid and oxalic acid are primarily present in cells for cation charge (Uren, 2000). In rice, greater exudation of malic acid was associated with increased $\mathrm{Zn}$ efficiency (Hajiboland et al., 2005). Meanwhile, solubilisation of zinc sulfate is dependent on exudation of citrate from rice in a small amount. It also appears to be dependent on proton excretion and $\mathrm{pH}$ reduction (Duffner et al., 2012). Organic acids are more advantageous than highmolecular-weight compounds as they are mobile and readily assimilated by a wide range of microorganisms like zinc-solubilizing bacteria (ZSB) (Szmigielska et al., 1985; Robert, 1986). The ZSB are able to produce 2ketogluconic acid and oxalic acid during $\mathrm{Zn}$ solubilisation process (Simine and Gadd, 1998; Fasim et al., 2002). Previous studies showed that ZSB produced high organic acids during zinc sulfate solubilisation but it varied during the plant growth period.

To date, very little work has been directed on the utilization of organic acid to solubilize Zn (Ebrahimian and Bybordi, 2012). Many researchers also found inconsistent results of $\mathrm{Zn}$ solubilisation through the production of organic acids by bacteria and plants (Hajiboland et al., 2005; Shakeel et al., 2015). The inconsistent results were due to many factors. The factors are, plant species itself, competition with indigenous bacteria, different types and amounts of organic acid production during growth. Thus, it is very 
important to determine the effects of ZSB inoculation, organic acids and rates of organic acids on $\mathrm{Zn}$ uptake and plant growth of rice using zinc sulfate fertilizer. Hence, the present study objectives are to determine the effects of different types and rates of organic acids application on $\mathrm{Zn}$ solubilisation and to determine the effects of ZSB inoculation, types and rates of organic acids on growth and $\mathrm{Zn}$ uptake of the rice plant.

\section{Materials and methods}

2.1 Solubilization of zinc source by different organic acids

Laboratory studies were conducted to test the solubility of $\mathrm{Zn}$ by two types of organic acids at four rates. Commercial malic acid (SIGMA) and citric acid (SIGMA) was used to solubilise zinc oxide, zinc carbonate and zinc sulfate at four different rates $(0,0.1$, 1.0 and $10 \mathrm{mM})$. The tests were carried out using Petri dishes with $20 \mathrm{~mL}$ of modified minimal salts medium agar amended with different $\mathrm{Zn}$ sources. Each of the organic acid $(0.1 \mathrm{~mL})$ was added into the wells in the agar with a diameter of $7 \mathrm{~mm}$. Halozone formation around the well indicated positive results then clearing zone around the well was measured. About $0.1 \mathrm{~mL}$ of each organic acid was also pipetted to the medium amended with insoluble $\mathrm{Zn}$ and analysed for the availability of $\mathrm{Zn}$ using atomic absorbance spectrophotometer (AAS) (Perkin-Elmer 400). This method was modified from Fomina et al. (2005).

2.2 Growth chamber study of the effects of ZSB inoculation, organic acids types and rates on rice plant

\subsubsection{Experimental design for sand culture under} controlled condition

The experiment was arranged in a completely randomized design. The treatments were arranged in a 2 $\mathrm{x} 2$ x 4 factorial design, with three replications. The total samples were forty-eight samples. The first factor consisted of two inoculation types which were, inoculated with ZSB Acinetobacter sp. (TM56) and noninoculated. The second factor was two treatments derived from different sources of organic acids which were malic acid and citric acid. While the third factor consisted of four different rates of organic acids $(0,0.1$, 1.0 and $10 \mathrm{mM})$. Organic acids were weighed and put into four $1 \mathrm{~L}$ sterilized distilled water to make the concentration $(0,0.1,1.0$ and $10 \mathrm{mM})$ as required. During inoculation, individual organic acid solution (1 $\mathrm{mL}$ ) was applied to each planting unit according to treatments. Zinc sulfate at $0.2 \mathrm{mg} / \mathrm{L}$ used in Hoagland nutrient solution. Plants were grown for 40 days in a growth chamber with $12 \mathrm{hr}$ light/dark cycle at $29 \pm 1{ }^{\circ} \mathrm{C}$ temperature.

\subsubsection{Seed surface sterilization}

The seed surface sterilization was determined based on Amin et al. (2004). Rice seeds were dehusked and shaken in $70 \%$ ethanol for five mins. The ethanol was then discarded and the seeds were agitated in hypochlorite solution comprising 3\% of Clorox $(2.6 \%$ $\mathrm{NaOCl})$. Next, the seeds were washed using sterilized distilled water. After three rinses of sterile water, the seeds were rinsed with sodium thiosulphate solution (2\%) to neutralize the chloramine residue on the seeds. Lastly, the efficacy of sterilization was checked by germinating seeds on nutrient agar.

\subsubsection{Preparation of sand culture}

Sands were sieved with $2.0 \mathrm{~mm}$ sieve and soaked overnight with $0.1 \mathrm{M}$ of hydrochloric acid $(\mathrm{HCl})$. Subsequently, the sands were washed several times with distilled water until $\mathrm{pH} 6.0$ obtained. The sand was then air-dried and sterilised using autoclave at $15 \mathrm{psi}$ and $121^{\circ}$ $\mathrm{C}$ for 15 mins. Prior to transplanting, the sand was soaked with $200 \mathrm{~mL}$ of sterile $\mathrm{Zn}$ free plant Hoagland growth medium. Zinc was supplied using $\mathrm{Zn}$ sulfate and $\mathrm{Zn}$ oxide. The treatment rates were $0,0.2$ and $0.4 \mathrm{mg} / \mathrm{L}$ for each $\mathrm{Zn}$ source. The nutrient solution was applied weekly to the plants until 40 days of growth. Plants were grown in the growth chamber with $12 \mathrm{hr}$ light/dark cycles at $28^{\circ} \mathrm{C}$ (Naher et al., 2009).

\subsubsection{Preparation of bacterial inoculums and inoculation of rice seedlings}

Isolate Acinetobacter sp. (TM56) were grown for 48$72 \mathrm{hrs}$ in nutrient broth. The bacterial cells were harvested by centrifugation at $13500 \times g$ for 10 mins in an Eppendorf tube and were further washed using phosphate buffer saline (PBS).

\subsection{Determination of plant growth parameters}

Plant height was recorded after 40 days of growing period. While, for plant biomass, the plant samples were dried in an oven at $70^{\circ} \mathrm{C}$ for five days until a constant weight was obtained and then the weight was recorded.

\subsection{Zinc tissue analysis}

Plant samples were dried in an oven at $70^{\circ} \mathrm{C}$ for five days. Next, the dried plants were ground finely and 100 $\mathrm{mg}$ of the plant tissue was placed in a $100 \mathrm{~mL}$ digestion tube containing $10 \mathrm{~mL}$ nitric acid $\left(\mathrm{HNO}_{3}\right)$ and perchloric acid $\left(\mathrm{HClO}_{4}\right)$ at 9:4 ratios. The tubes were placed on digestion block, and the entire plant material was digested at $300^{\circ} \mathrm{C}$ until it turned colourless and left to cool in a fume hood. Then, the extract was put into 100 $\mathrm{mL}$ volumetric flask, and distilled water was added until 
the volume reached $100 \mathrm{~mL}$. These samples were used for the estimation of $\mathrm{Zn}$ concentration and $\mathrm{Zn}$ uptake. $\mathrm{Zn}$ concentration in the plant was estimated using AAS (Perkin-Elmer, 400). Zinc uptake by the plant was determined as $\mathrm{Zn}$ concentration multiplied by the plant dry weight (Goteti et al., 2013).

\subsection{Bacterial population of inoculated treatments}

\subsubsection{Determination of non-rhizosphere}

After 40 days of growth, about $10 \mathrm{~g}$ of sand was taken from each sampling unit and added into $90 \mathrm{~mL}$ sterile distilled water and shaken using a vortex. A series of 10 -fold dilution up to $10^{11}$ was prepared. Aliquots of $0.1 \mathrm{~mL}$ from each dilution were dropped onto nutrient agar and populations were determined using the drop plate count method (Somasegaran and Hoben, 1985).

\subsubsection{Determination of rhizosphere}

During harvesting, around $1.0 \mathrm{~g}$ of plant roots were washed gently using sterile water and placed in a conical flask containing $99 \mathrm{~mL}$ distilled water. The content in the flask was shaken for 15 mins, and a series of 10-fold dilutions were prepared, and bacterial populations were determined as prescribed previously.

\subsubsection{Determination of root endosphere}

Approximately $1.0 \mathrm{~g}$ of roots were washed, and surface sterilized with $70 \%$ ethanol for 5 mins. Subsequently, it was treated with 3\% Clorox for $1 \mathrm{~min}$. After several washes with sterile distilled water, the roots were meshed using a sterilized mortar and pestle (Gyaneswar et al., 2001). Then, the roots were checked for the efficacy of surface sterilization. A 10-fold series of dilution was prepared up to $10^{-10}$ and the diazotrophic populations were measured as described previously.

\subsection{Data analysis}

Data for $\mathrm{Zn}$ solubilization by commercial organic acids consisted of different $\mathrm{Zn}$ source and rates of organic acids. The data were subjected to ANOVA and post hoc Tukey's HSD test for mean comparison. Similarly, for growth chamber experiment, data for the treatment ZSB inoculation factor consisted of inoculated and non-inoculated, treatments factor of organic acid with malic acid and citric along with four rates of organic acids $(0,0.1,1.0$ and $10 \mathrm{mM})$ were subjected to ANOVA and treatment means were compared using Tukey's HSD test $(\mathrm{p}<0.05)$. All data were statistically analysed using the SAS Software program (Version 9.4).

\section{Results and discussion}

\subsection{Zn solubilisation by different types of organic acids}

Organic acids could solubilize different forms of $\mathrm{Zn}$ sources used in the study (zinc oxide, zinc sulfate, and zinc phosphate) (Figure 1). Interaction of $\mathrm{Zn}$ sources, types of organic acid and rates of organic acid significantly affected $\mathrm{Zn}$ solubilisation at $\mathrm{p}<0.05$. A significant increase of $\mathrm{Zn}$ solubilization was recorded in malic acid at $10 \mathrm{mM}$. The highest increase of $\mathrm{Zn}$ solubilization was zinc sulfate with $0.79 \mathrm{mg} / \mathrm{L}$ compared to zinc oxide and zinc carbonate. A similar observation was recorded for citric acid. The higher rates of citric, the higher zinc oxide, zinc carbonate and zinc sulfate that were solubilized (Figure 1). Whereby high $\mathrm{Zn}$ solubility was in zinc sulfate at $0.50 \mathrm{mg} / \mathrm{L}$ at $10 \mathrm{mM}$ of citric acid. Overall, the solubility of $\mathrm{Zn}$ in mineral salts media was directly proportional to the concentration of the organic acid. Increasing concentration of organic acid showed the trends of increasing $\mathrm{Zn}$ solubilisation activity.

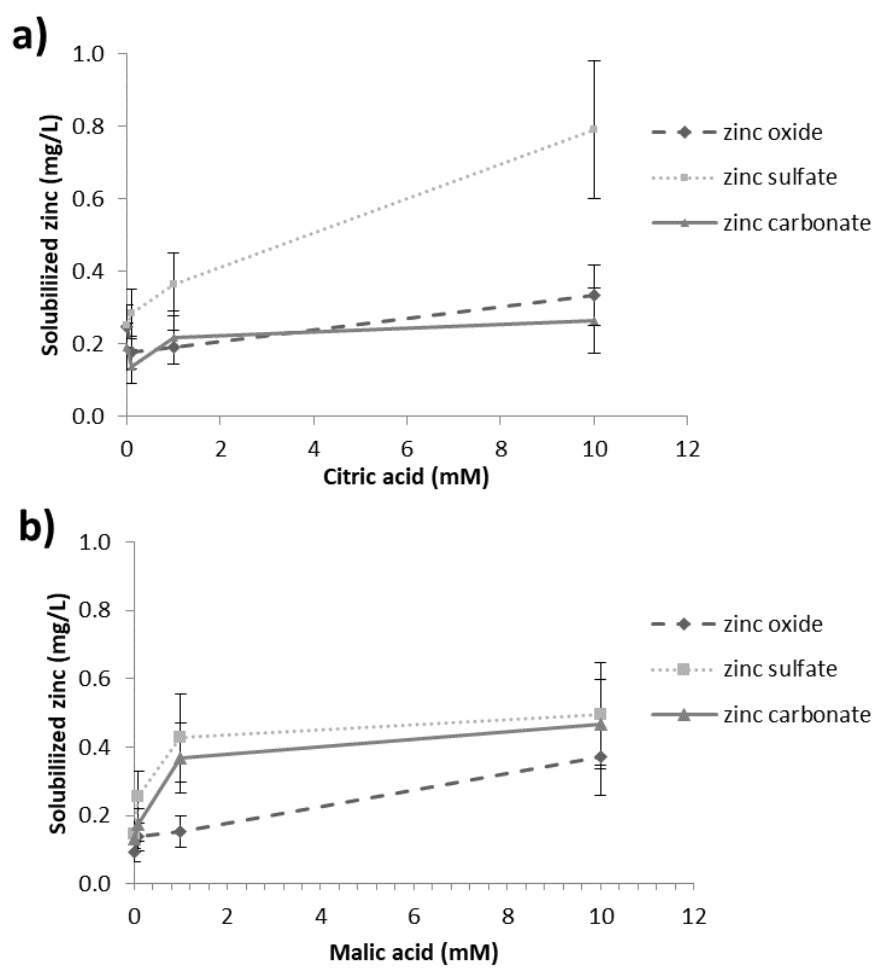

Figure 1. Zn solubilisation using organic acids in liquid media with a) citric acid and b) malic acid. Bars indicate standard error, $n=3$

\subsection{Effect of ZSB inoculation, types of organic acids and its rates on growth of rice}

Plant biomass was significantly affected by ZSB inoculation, types of organic acids and rates of organics acids at $\mathrm{p}<0.05$ (Table 1). In inoculated treatment, plant biomass that was applied with malic acid showed a significant increase from 0 to $0.1 \mathrm{mM}$, then plant biomass was significantly decreased from 1.0 to $10 \mathrm{mM}$ (Figure 2). While, for citric acid, plant biomass 

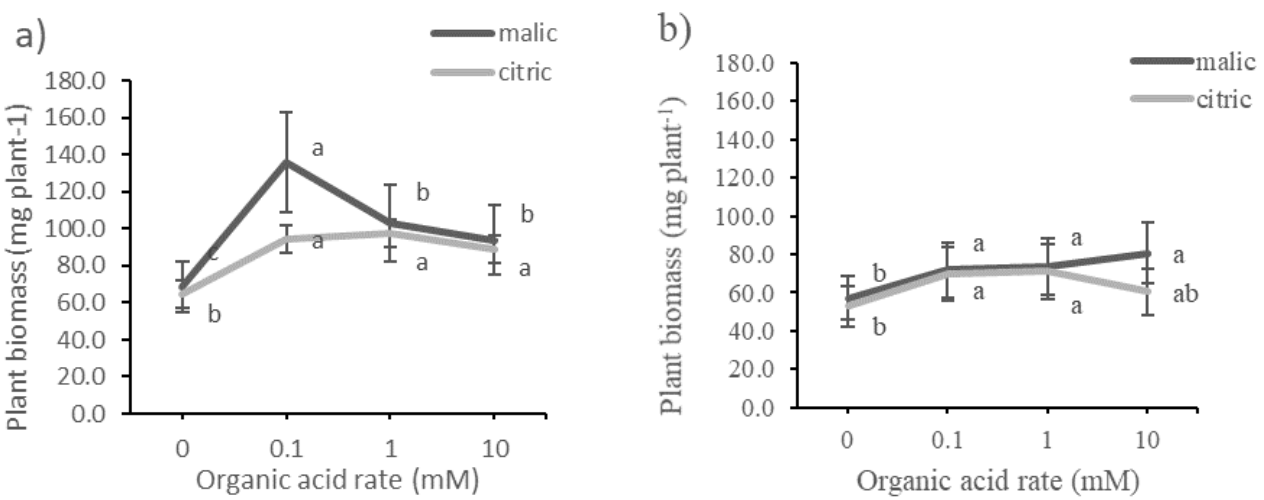

Figure 2. Effects of ZSB Inoculation, types of organic acid and its rates on plant biomass of rice plant: a) inoculated and b) noninoculated.

Bars indicated standard error. Means with the same letter within rates of malic acid and citric acid are not significantly different at $\mathrm{P}>0.05$

significantly increased from 0 to $0.1 \mathrm{mM}$. However, there was no further increase from 1.0 to $10 \mathrm{mM}$ of citric acid. In non-inoculated treatment, plant biomass for plants receiving the application of malic acid and citric acid were significantly increased from 0 to $0.1 \mathrm{mM}$. Then, there were no further increased at 1.0 and $10 \mathrm{mM}$. The highest $(135.67 \mathrm{mg})$ plant biomass was recorded from inoculated treatment with malic acid at $0.1 \mathrm{mM}$ compared to without application of organic acids.

Table 1. Effects of ZSB inoculation, organic acid types and rates on plant biomass

\begin{tabular}{lc}
\hline Treatment factor & $\begin{array}{c}\text { Plant biomass } \\
\left(\mathrm{mg} \mathrm{plant}^{-1}\right)\end{array}$ \\
\hline ZSB inoculation & \\
\hline Non-inoculated & $93.33^{\mathrm{a}}$ \\
Inoculated & $67.13^{\mathrm{b}}$ \\
\hline Organic acid & \\
\hline Malic acid & $85.54^{\mathrm{a}}$ \\
Citric acid & $74.92^{\mathrm{b}}$ \\
\hline Organic acid rate $(\mathrm{mM})$ & \\
\hline 0 & $60.75^{\mathrm{c}}$ \\
0.1 & $92.92^{\mathrm{a}}$ \\
1 & $86.25^{\mathrm{b}}$ \\
10 & $81.00^{\mathrm{b}}$ \\
\hline
\end{tabular}

\begin{tabular}{lc}
\hline Significance level & \\
\hline ZSB & $* * *$ \\
Organic acids & $* * *$ \\
ZSB*Organic acids & $* *$ \\
Rates of organic acid & $* * *$ \\
ZSB*Rates of Organic acid & $* * *$ \\
Organic acids*Rates of organic acids & $* *$ \\
ZSB Organic acids*Rates of organic acid & $* * *$ \\
CV & 6.51 \\
\hline
\end{tabular}

$\mathrm{P}<0.05 ; * * \mathrm{P}<0.01 ; * * * \mathrm{P}<0.001, \mathrm{ZSB}=$ Zinc-solubilizing bacteria Acinetobacter sp (TM56)

Values with the same superscript among ZSB inoculation, organic acid types and organic acid rates are not significantly different at $\mathrm{P}>0.05$.
There was a significant interaction for ZSB inoculation, organic acids and organic acids rates for plant height at $\mathrm{p}<0.001$ (Table 2). In inoculated treatment, plant height was significantly increased when applied with malic acid from 0 to $0.1 \mathrm{mM}$ (Figure 3). However, plant height decreased when malic acid reached 1.0 and then $10 \mathrm{mM}$. While for citric acid, plant height decreased from 0 to $0.1 \mathrm{mM}$. There was no significant increase of $1.0 \mathrm{mM}$ and $10 \mathrm{mM}$. In noninoculated treatment, malic acid showed an insignificant plant height from $0 \mathrm{mM}$ to $1.0 \mathrm{mM}$. Then, plant height decreased at $10 \mathrm{mM}$. While, for citric acid treatment, plant height significantly increased from 0 to $0.1 \mathrm{mM}$, then there was no significant increased at 1.0 to $10 \mathrm{mM}$.
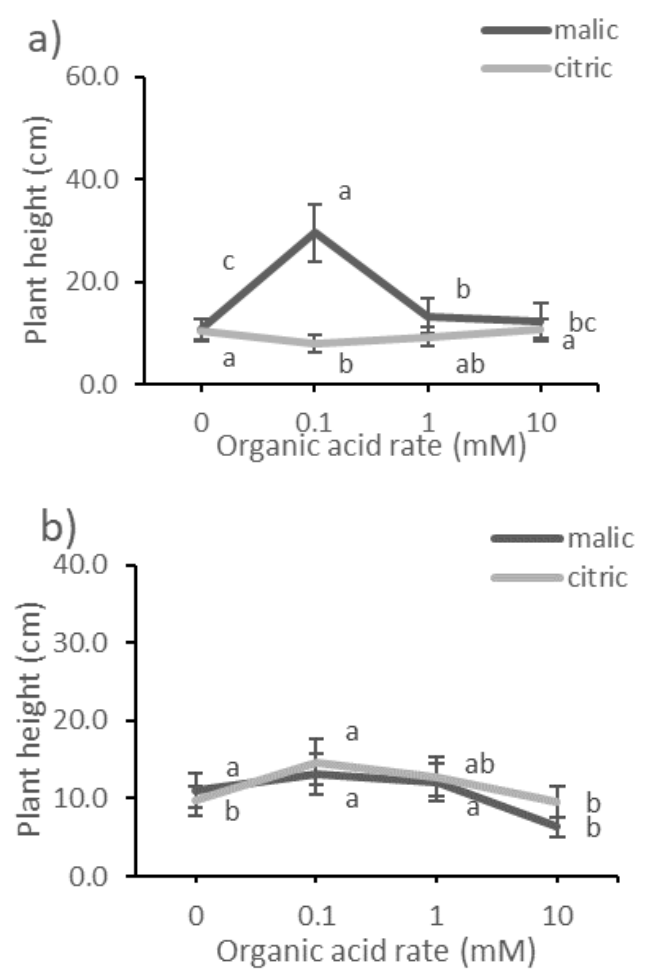

Figure 3. Effects of ZSB Inoculation, types of organic acids and its rates on plant height of rice plant: a) inoculated and b) noninoculated rice plant. Bars indicated standard error. Means with the same letter within rates of malic acid and citric acid are not significantly (NS) different at $\mathrm{P}>0.05$ 
Among all, the highest $(29.57 \mathrm{~cm})$ plant height was recorded for inoculated treatment with $0.1 \mathrm{mM}$ compared to control.

Table 2. Effects of ZSB inoculation, organic acid types and rates of organic acids on rice plant height

\begin{tabular}{lc}
\hline Treatment factor & Plant height $(\mathrm{cm})$ \\
\hline ZSB inoculation & \\
\hline Non-inoculated & $11.16^{\mathrm{b}}$ \\
Inoculated & $13.10^{\mathrm{a}}$ \\
\hline Organic acid & \\
\hline Malic acid & $13.60^{\mathrm{a}}$ \\
Citric acid & $10.65^{\mathrm{b}}$ \\
\hline Organic acid rate $(\mathrm{mM})$ & \\
\hline 0 & $10.49^{\mathrm{c}}$ \\
0.1 & $16.33^{\mathrm{a}}$ \\
1 & $11.93^{\mathrm{b}}$ \\
10 & $9.76^{\mathrm{c}}$ \\
\hline
\end{tabular}

\begin{tabular}{ll}
\hline Significance level & \\
\hline ZSB & $* * *$ \\
Organic acids & $* * *$ \\
ZSB*Organic acids & $* * *$ \\
Rates of organic acid & $* * *$ \\
ZSB*Rates of Organic acid & $* * *$ \\
Organic acids*Rates of organic acids & $* * *$ \\
ZSB*Organic acids*Rates of organic acid & $* * *$ \\
CV & 9.68 \\
\hline
\end{tabular}

$* \mathrm{P}<0.05 ; * * \mathrm{P}<0.01 ; * * * \mathrm{P}<0.001, \mathrm{ZSB}=$ Zinc-solubilizing bacteria Acinetobacter sp (TM56)

Values with the same superscript among ZSB inoculation, organic acid types and organic acid rates are not significantly different at $\mathrm{P}>0.05$.

\subsection{Effect of ZSB inoculation, organic acid types and} rates of organic acids on relative chlorophyll contents in rice plant leaves

Relative of chlorophyll content of plant leaves was significantly affected by the interaction of ZSB inoculation, organic acids and organic acid rates at $\mathrm{p}<0.001$ (Table 3). For inoculated treatment, relative chlorophyll contents increased with the application of malic acid from 0 to $0.1 \mathrm{mM}$ (Figure 4). However, the amount decreased when malic acid concentration reached 1.0 to $10 \mathrm{mM}$. For citric acid, there was also a significant increase in plant biomass from 0 to $0.1 \mathrm{mM}$. Then, there was a significant decrease at $1.0 \mathrm{mM}$ followed by a significant decrease at $10 \mathrm{mM}$. For noninoculated treatment, there was a similar increase from 0 to $0.1 \mathrm{mM}$ of malic acid and citric acid. However, there was no further increase in relative chlorophyll content at 1.0 and $10 \mathrm{mM}$ of citric acid. While, for malic acid, there

Table 3. Effects of ZSB inoculation, organic acid types and rates of organic acids on relative chlorophyll content in rice plant.

\begin{tabular}{lc}
\hline Treatment factor & $\begin{array}{c}\text { Relative chlorophyll } \\
\text { content }\end{array}$ \\
\hline ZSB inoculation & $15.45^{\mathrm{b}}$ \\
\hline Non-inoculated & $20.44^{\mathrm{a}}$ \\
\hline Inoculated & \\
\hline Organic acid & $19.31^{\mathrm{a}}$ \\
\hline Malic acid & $16.58^{\mathrm{b}}$ \\
\hline Citric acid & \\
\hline Organic acid rate $(\mathrm{mM})$ & $15.95^{\mathrm{b}}$ \\
\hline 0 & $22.63^{\mathrm{a}}$ \\
0.1 & $16.87^{\mathrm{b}}$ \\
1 & $16.33^{\mathrm{b}}$ \\
\hline 10 & \\
\hline Significance level & $* * *$ \\
\hline ZSB & $* * *$ \\
Organic acids & $* * *$ \\
ZSB*Organic acids & $* * *$ \\
Rates of organic acid & $* * *$ \\
ZSB Rates of Organic acid & $* * *$ \\
Organic acids*Rates of organic acids & $* * *$ \\
ZSB*Organic acids*Rates of organic acid & 4.83 \\
CV &
\end{tabular}

$* \mathrm{P}<0.05 ; * * \mathrm{P}<0.01 ; * * * \mathrm{P}<0.001, \mathrm{ZSB}=$ Zinc-solubilizing bacteria Acinetobacter sp (TM56)

Values with the same superscript among ZSB inoculation, organic acid types and organic acid rates are not significantly different at $\mathrm{P}>0.05$.
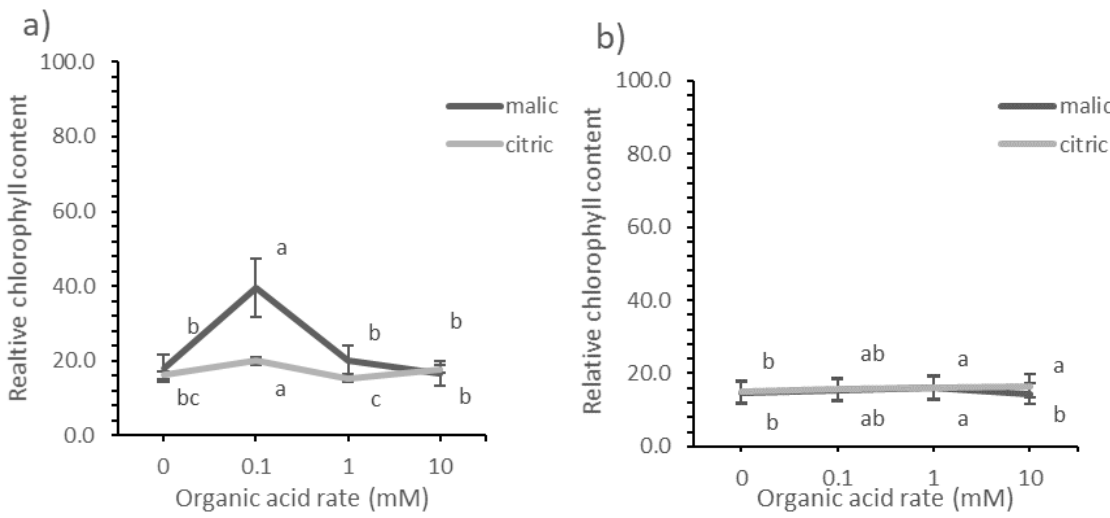

Figure 4. Effects of ZSB Inoculation, Organic Acids and its rates on relative chlorophyll content in rice plant: a) inoculated and b) non-inoculated. Bars indicated standard error. Means with the same letter within rates of malic acid and citric acid are not significantly (NS) different at $\mathrm{P}>0.05$ 
was a significant decrease at $10 \mathrm{mM}$ of its application. Among all, the application of malic acid at $0.1 \mathrm{mM}$ showed the highest (39.57) relative chlorophyll content compared to without malic acid applied to the plant.

\subsection{Effects of ZSB inoculation, organic acid types and rates of organic acids on $\mathrm{Zn}$ concentration in rice}

A significant interaction of ZSB inoculation, organic acid types and the organic acid rate was detected for $\mathrm{Zn}$ concentration at $\mathrm{p}<0.001$ (Table 4). In inoculated treatment, $\mathrm{Zn}$ concentration was significantly increased with the application of malic acid from 0 to $0.1 \mathrm{mM}$ (Figure 5). Then, $\mathrm{Zn}$ concentration significantly decreased at $1.0 \mathrm{mM}$ and no further decrease at $10 \mathrm{mM}$. While for citric acid, there was a significant decrease from 0 to $1.0 \mathrm{mM}$. However, there was a significant increase at $10 \mathrm{mM}$ of citric acid application. In noninoculated treatment, malic acid showed a significant increase in $\mathrm{Zn}$ concentration from 0 to $1.0 \mathrm{mM}$. No further increase was observed at $10 \mathrm{mM}$. While for citric acid, there was a significant increase from 0 to $0.10 \mathrm{mM}$. Then, there was a significant decrease at $1.0 \mathrm{mM}$ and 10 $\mathrm{mM}$. Highest $\left(52.20 \mathrm{mg} \mathrm{kg}^{-1}\right.$ ) $\mathrm{Zn}$ concentration was recorded for inoculated treatment which applied with malic acid at $0.1 \mathrm{mM}$ compared to no application of organic acids.

Table 4. Effects of ZSB inoculation, organic acid types and rates on $\mathrm{Zn}$ concentration in rice

\begin{tabular}{lc}
\hline Treatment factor & $\begin{array}{c}\text { Zn concentration } \\
\left(\mathrm{mg} \mathrm{kg}^{-1}\right)\end{array}$ \\
\hline ZSB inoculation & \\
\hline Non-inoculated & $26.69^{\mathrm{b}}$ \\
Inoculated & $26.99^{\mathrm{a}}$ \\
\hline Organic acid & \\
\hline Malic acid & $26.73^{\mathrm{a}}$ \\
Citric acid & $22.94^{\mathrm{b}}$ \\
\hline Organic acid rate $(\mathrm{mM})$ & \\
\hline 0 & $21.83^{\mathrm{b}}$ \\
0.1 & $32.70^{\mathrm{a}}$ \\
1 & $23.98^{\mathrm{b}}$ \\
10 & $20.83^{\mathrm{b}}$
\end{tabular}

Significance level

\section{ZSB}

Organic acids

ZSB*Organic acids

Rates of organic acid

ZSB*Rates of Organic acid

Organic acids*Rates of organic acids

ZSB*Organic acids*Rates of organic acid

$\mathrm{CV}$
$* *$

$* *$

$*$

$* * *$

$* * *$

ns

$* * *$

16.37
$* \mathrm{P}<0.05 ; * * \mathrm{P}<0.01 ; * * * \mathrm{P}<0.001, \mathrm{ZSB}=$ Zinc-solubilizing bacteria Acinetobacter sp (TM56)

Values with the same superscript among ZSB inoculation, organic acid types and organic acid rates are not significantly different at $\mathrm{P}>0.05$.
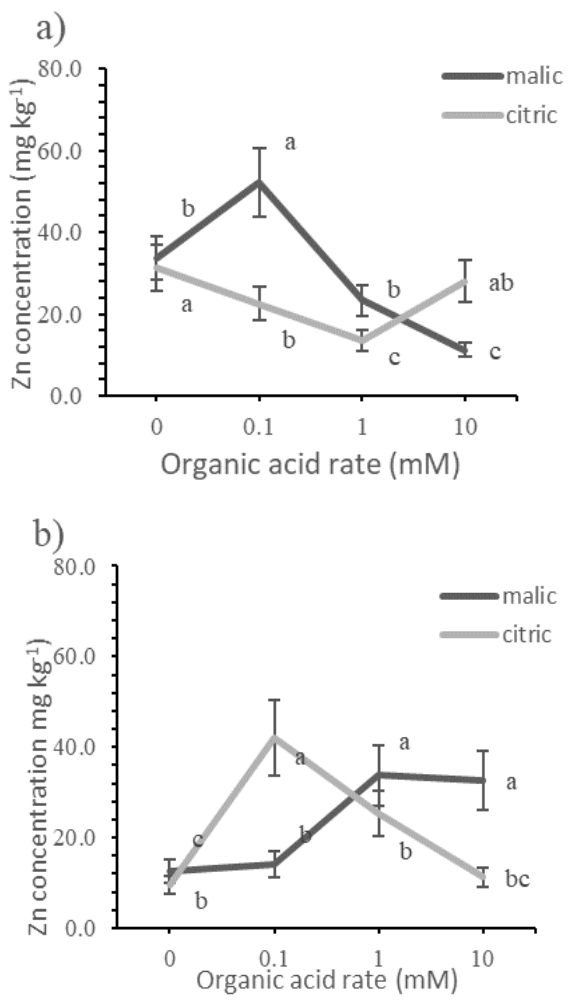

Figure 5. Effects of ZSB Inoculation, types of organic Acids and its rates on $\mathrm{Zn}$ concentration of rice plant: a) inoculated and b) non-inoculated

Bars indicated standard error. Means with the same letter within rates of malic acid and citric acid are not significantly (NS) different at $\mathrm{P}>0.05$.

\subsection{Effect of ZSB inoculation, organic acid types and rates of organic acids on Zn uptake in rice plant}

Interaction of ZSB inoculation, organic acids and rate of organic acids affected $\mathrm{Zn}$ uptake at $\mathrm{p}<0.001$ (Table 5). In inoculated treatment, there was a significant increase of $\mathrm{Zn}$ uptake from 0 to $0.1 \mathrm{mM}$ of malic acid application, then, a significant decrease from $1.0 \mathrm{mM}$ to $10 \mathrm{mM}$. While for citric acid application, there was a significant decrease from 0 to $1.0 \mathrm{mM}$. However, at 10 $\mathrm{mM}$ there was a significant increase of $\mathrm{Zn}$ uptake detected (Figure 6). In non-inoculated treatment, malic acid showed a similar increase from 0 to $0.1 \mathrm{mM}$. However, at $1.0 \mathrm{mM}$, there was a significant increase then no further increase observed at $10 \mathrm{mM}$. While for citric acid, a significant increase was observed from 0 to $1.0 \mathrm{mM}$. However, the application of citric acid showed a significant decrease of $\mathrm{Zn}$ uptake from concentration 1.0 to $10 \mathrm{mM}$. Highest ( $777.64 \mathrm{mg} / 3$ plants) $\mathrm{Zn}$ uptake was recorded for inoculated treatment with malic acid at $0.1 \mathrm{mM}$ compared to non-malic acid application to the plants.

3.6 Effect of ZSB, organic acid types and rates of organic acid to root development of rice plant

There was an interaction of variable ZSB, types of 
Table 5. Effects of ZSB inoculation, organic acid types and organic acid rates on $\mathrm{Zn}$ uptake of rice

\begin{tabular}{lc}
\hline Treatment factor & $\begin{array}{c}\text { Zn uptake } \\
(\mathrm{mg} / 3 \text { plants })\end{array}$ \\
\hline ZSB inoculation & $157.64^{\mathrm{b}}$ \\
\hline Non-inoculated & $269.16^{\mathrm{a}}$ \\
\hline Inoculated & \\
\hline Organic acid & $253.46^{\mathrm{a}}$ \\
\hline Malic acid & $173.34^{\mathrm{b}}$ \\
Citric acid & \\
\hline Organic acid rate $(\mathrm{mM})$ & $134.68^{\mathrm{c}}$ \\
\hline 0 & $347.33^{\mathrm{a}}$ \\
0.1 & $199.28^{\mathrm{b}}$ \\
1 & $172.31^{\mathrm{bc}}$ \\
10 & $* * *$ \\
\hline Significance level & $* * *$ \\
\hline ZSB & $* * *$ \\
Organic acids & $* * *$ \\
ZSB Organic acids & $* * *$ \\
Rates of organic acid & $* * *$ \\
ZSB*Rates of Organic acid & $* * *$ \\
Organic acids*Rates of organic acids & 18.33 \\
ZSB Organic acids $*$ Rates of organic acid &
\end{tabular}

$* \mathrm{P}<0.05 ; * * \mathrm{P}<0.01 ; * * * \mathrm{P}<0.001, \mathrm{ZSB}=$ Zinc-solubilizing bacteria Acinetobacter sp (TM56)

Values with the same superscript among ZSB inoculation, organic acid types and organic acid rates are not significantly different at $\mathrm{P}>0.05$.

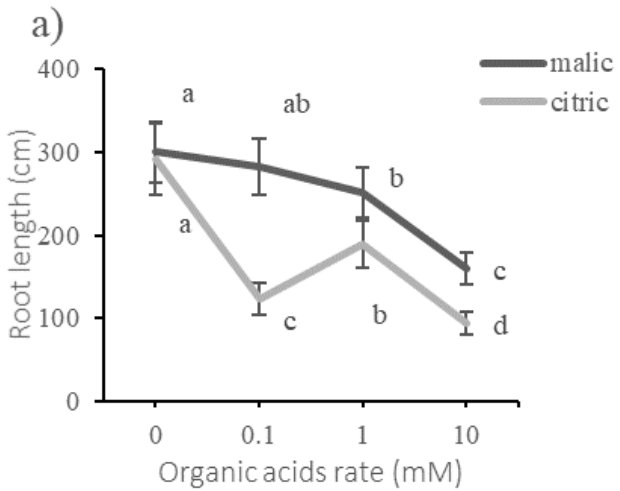

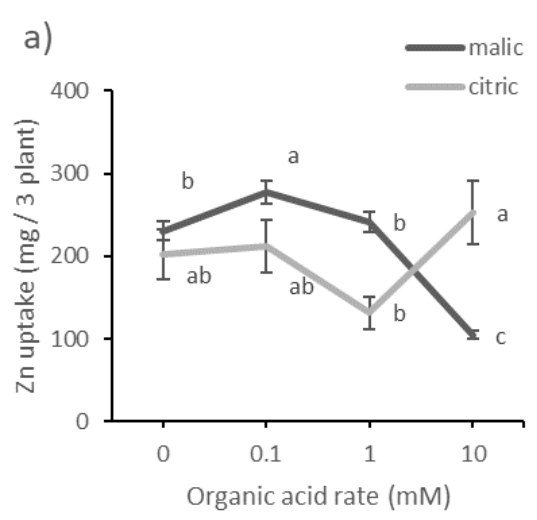

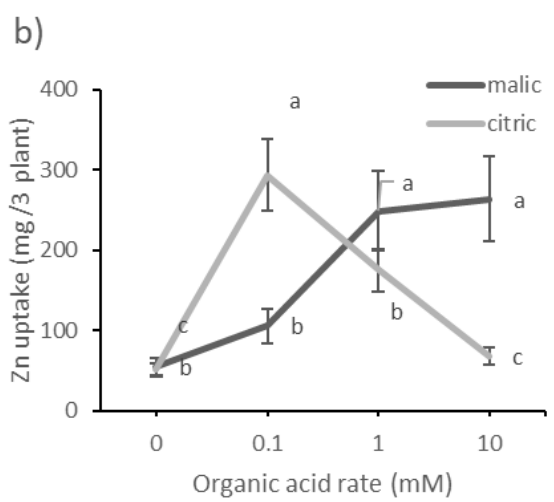

Figure 6. Effects of ZSB inoculation, types of organic acids and its rates on $\mathrm{Zn}$ uptake of rice plant: a) non-inoculated and b) inoculated.

Bars indicated standard error. Means with the same letter within rates of malic acid and citric acid are not significantly (NS) different at $\mathrm{P}>0.05$

b)

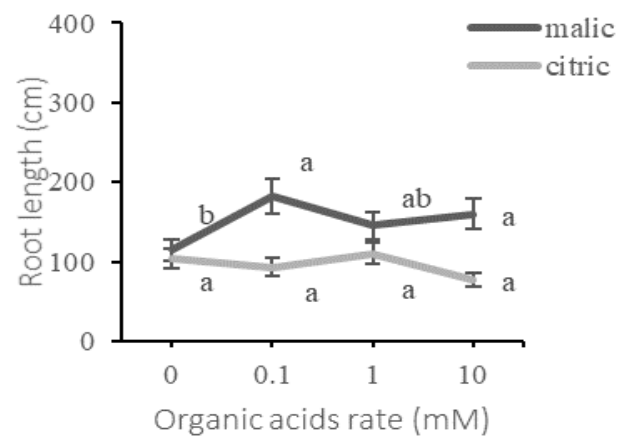

Figure 7. Effects of ZSB inoculation, organic acids types and rates on root length for rice plant; a) inoculated and b) noninoculated.

Bars indicated standard error. Means with the same letter within rates of malic acid and citric acid are not significantly (NS) different at $\mathrm{P}>0.05$

organic acids and organic acid rates at $\mathrm{p}<0.01$ (Table 6). For inoculated treatment, malic acid showed a significant decrease from 1.0 to $10 \mathrm{mM}$ of root length (Figure 7). While for citric acid, there was a significant decrease from 0 to $0.1 \mathrm{mM}$, then root length significantly increased at $1.0 \mathrm{mM}$ before decreased again at $10 \mathrm{mM}$ (Figure 30). For non-inoculated treatment, malic acid showed a significant increase from $0 \mathrm{mM}$ to $0.1 \mathrm{mM}$. There was no further increase of $1.0 \mathrm{mM}$ and $10 \mathrm{mM}$. While for citric acid, there was no significant increase from 0 to $1.0 \mathrm{mM}$. However, there was a significant decrease in root length when applied with citric acid at $10 \mathrm{mM}$. Root volume was affected by the interaction of ZSB inoculation, organic acid types and organic acids rates at $\mathrm{p}<0.01$ (Table 6 ). For inoculated treatment, only malic acid affected root volume where at $0.1 \mathrm{mM}$ root volume was significantly increased and then decreased when the rate approached $1.0 \mathrm{mM}$ and $10 \mathrm{mM}$ (Figure $8)$. However, for citric acid, similar root volume was observed for all of the rates. Highest $\left(0.408 \mathrm{~cm}^{3}\right)$ root volume was detected from treatment consisted of malic acid at $0.1 \mathrm{mM}$ with $\mathrm{ZSB}$ inoculation compared to non- 
Table 6. Effects of ZSB, organic acids and rates of organic acids on root development of rice plant

\begin{tabular}{|c|c|c|c|c|}
\hline Treatment factor & Root length $(\mathrm{cm})$ & Root volume $\left(\mathrm{cm}^{3}\right)$ & Root diameter $(\mathrm{cm})$ & Root area $\left(\mathrm{cm}^{2}\right)$ \\
\hline \multicolumn{5}{|l|}{ ZSB inoculation } \\
\hline Non-inoculated & $123.29^{b}$ & $0.12^{b}$ & $0.33^{\mathrm{a}}$ & $0.12^{b}$ \\
\hline Inoculated & $211.18^{\mathrm{a}}$ & $0.20^{\mathrm{a}}$ & $0.32^{\mathrm{a}}$ & $0.20^{\mathrm{a}}$ \\
\hline \multicolumn{5}{|l|}{ Organic acid } \\
\hline Malic acid & $199.14^{\mathrm{a}}$ & $0.19^{\mathrm{a}}$ & $0.33^{\mathrm{a}}$ & $0.19^{\mathrm{a}}$ \\
\hline Citric acid & $135.33^{b}$ & $0.12^{\mathrm{b}}$ & $0.32^{\mathrm{a}}$ & $0.11^{\mathrm{b}}$ \\
\hline \multicolumn{5}{|l|}{ Organic acid rate } \\
\hline 0 & $202.54^{\mathrm{a}}$ & $0.14^{\mathrm{b}}$ & $0.38^{\mathrm{a}}$ & $0.13^{\mathrm{a}}$ \\
\hline 0.1 & $169.99^{b}$ & $0.20^{\mathrm{a}}$ & $0.33^{\mathrm{ab}}$ & $0.23^{\mathrm{a}}$ \\
\hline 1 & $173.77^{\mathrm{b}}$ & $0.15^{\mathrm{b}}$ & $0.31^{\mathrm{bc}}$ & $0.12^{\mathrm{a}}$ \\
\hline 10 & $122.65^{\mathrm{c}}$ & $0.13^{\mathrm{b}}$ & $0.27^{\mathrm{c}}$ & $0.14^{\mathrm{a}}$ \\
\hline \multicolumn{5}{|l|}{ Significance level } \\
\hline$\overline{\mathrm{ZSB}}$ & $* * *$ & $* * *$ & ns & $*$ \\
\hline Organic acids & $* * *$ & $* * *$ & ns & $*$ \\
\hline ZSB*Organic acids & $*$ & $* *$ & ns & $\mathrm{ns}$ \\
\hline Rates of organic acid & $* * *$ & $* *$ & $* * *$ & ns \\
\hline ZSB*Rates of Organic acid & $* * *$ & ** & ns & ns \\
\hline Organic acids*Rates of organic acids & $* * *$ & $* *$ & ns & ns \\
\hline ZSB*Organic acids*Rates of organic acids & $* *$ & $* *$ & ns & ns \\
\hline $\mathrm{CV}$ & 8.73 & 26.6 & 15.22 & 41.48 \\
\hline
\end{tabular}

$* \mathrm{P}<0.05 ; * * \mathrm{P}<0.01 ; * * * \mathrm{P}<0.001, \mathrm{~ns}=$ not significant, $\mathrm{ZSB}=$ Zinc-solubilizng bacteria Acinetobacter sp (TM56)

Values with the same superscript among ZSB inoculation, organic acid types and organic acid rates are not significantly (NS) different at $\mathrm{P}>0.05$

inoculated control. There was a significant difference in organic acid rates for root diameter at $\mathrm{p}<0.05$ (Table 6). Similar high root diameter was detected at rates $0.1,1.0$ and $10 \mathrm{mM}$ of organic acid rates compared to without organic acid application. A significant difference in organic acid types and inoculation types also detected for root area at $\mathrm{p}<0.05$ (Table 6). Malic acid showed a significantly higher $\left(0.193 \mathrm{~cm}^{2}\right)$ root area compared to citric acid. While for inoculation types, the inoculated treatment showed the highest $\left(0.20 \mathrm{~cm}^{2}\right)$ root area compared to non-inoculated.

\subsection{Effects of ZSB inoculation, organic acid types and rates on bacterial population}

There was no significant difference between organic acid types and rates at $\mathrm{p}<0.01$ for rhizosphere population and non-rhizosphere population (Table 7). While, A significant differences between malic acid and citric acid was detected only for endosphere population at $\mathrm{p}<0.01$. Malic acids showed higher (8.13 log $\left.10 \mathrm{CFU} \mathrm{mL} \mathrm{m}^{-1}\right)$ endosphere population than citric acid.

Table 7. Effects of organic acid types and rates on rhizosphere, endosphere and non-rhizosphere population of inoculated treatments.

\begin{tabular}{|c|c|c|c|}
\hline Treatment & $\begin{array}{l}\text { Rhizosphere population } \\
\left.(\mathrm{CFU} \mathrm{mL})^{-1}\right)\end{array}$ & 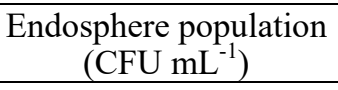 & $\begin{array}{c}\text { Non-rhizosphere } \\
\text { population }\left(\mathrm{CFU} \mathrm{mL} \mathrm{mL}^{-1}\right)\end{array}$ \\
\hline \multicolumn{4}{|l|}{ Organic acid types } \\
\hline Malic acid & $7.89^{\mathrm{a}}$ & $8.14^{\mathrm{a}}$ & $6.05^{\mathrm{a}}$ \\
\hline Citric acid & $7.53^{\mathrm{a}}$ & $7.43^{\mathrm{b}}$ & $5.88^{\mathrm{a}}$ \\
\hline \multicolumn{4}{|l|}{ Organic acid rates $(\mathrm{mM})$} \\
\hline 0 & $7.46^{\mathrm{a}}$ & $7.83^{\mathrm{a}}$ & $5.70^{\mathrm{b}}$ \\
\hline 0.1 & $7.80^{\mathrm{a}}$ & $7.73^{\mathrm{a}}$ & $6.38^{\mathrm{a}}$ \\
\hline 1 & $7.50^{\mathrm{a}}$ & $7.86^{\mathrm{a}}$ & $5.78^{\mathrm{b}}$ \\
\hline 10 & $8.06^{\mathrm{a}}$ & $7.70^{\mathrm{a}}$ & $6.00^{\mathrm{ab}}$ \\
\hline \multicolumn{4}{|l|}{ Significance level } \\
\hline Organic acid types & ns & $* *$ & ns \\
\hline Organic acids rates & ns & ns & $* *$ \\
\hline Organic acid types*organic acid rates & ns & ns & $\mathrm{ns}$ \\
\hline $\mathrm{CV}$ & 8.14 & 6.11 & 5.77 \\
\hline
\end{tabular}

$* * \mathrm{P}<0.01 ; \mathrm{ns}=$ not significant

Values with the same superscript among ZSB inoculation, organic acid types and organic acid rates are not significantly (NS) different at $\mathrm{P}>0.05$ 
3.8 Effects of ZSB inoculation, organic acid types and rates on $\mathrm{pH}$ of sand culture

There were significant differences between ZSB inoculation at $\mathrm{p}<0.01$ (Table 8). Inoculated treatment showed significantly higher (6.61) $\mathrm{pH}$ than noninoculated treatment. There was a similar $\mathrm{pH}$ detected between malic acid and citric acid and also among rates of organic acid tested.

Table 8. Effects of ZSB inoculation, organic acid types and rates on $\mathrm{pH}$ of sand culture

\begin{tabular}{ll}
\hline Treatment factor & $\mathrm{pH}$ \\
\hline ZSB inoculation & \\
\hline Non-inoculated & $6.45^{\mathrm{b}}$ \\
Inoculated & $6.61^{\mathrm{a}}$ \\
Organic acid & \\
Malic acid & $6.54^{\mathrm{a}}$ \\
Citric acid & $6.51^{\mathrm{a}}$ \\
\hline Organic acid rate & \\
\hline 0 & $6.52^{\mathrm{a}}$ \\
0.1 & $6.55^{\mathrm{a}}$ \\
1 & $6.52^{\mathrm{a}}$ \\
10 & $6.52^{\mathrm{a}}$ \\
\hline
\end{tabular}

Significance level

ZSB **

Organic acids

ZSB*Organic acids

Rates of organic acid

ZSB*Rates of Organic acid

$\mathrm{nS}$

Organic acids*Rates of organic acids

$*$

ZSB*Organic acids*Rates of organic acids

$\mathrm{CV}$

ns

ns

ns

ns

1.75

$* \mathrm{P}<0.05 ; * * \mathrm{P}<0.01 ; * * * \mathrm{P}<0.001, \mathrm{~ns}=$ not significant, ZSB = Zinc-solubilizng bacteria Acinetobacter sp (TM56)

Values with the same superscript among ZSB inoculation, organic acid types and organic acid rates are not significantly (NS) different at $\mathrm{P}>0.05$

\section{Discussion}

The results of $\mathrm{Zn}$ solubilisation by malic acid and citric acid revealed the influence of the type of organic acids and its concentration on $\mathrm{Zn}$ solubilisation. There was a significant effect of $\mathrm{Zn}$ types and organic acids rates on $\mathrm{Zn}$ solubility. This is because citric acid presents a high metal complexation strength with $\mathrm{Zn}$ (Madhaiyan et al., 2006; Huang et al., 2008; Labanowski et al., 2008). These observations were supported by Khademi et al. (2009), in which strong binding of citric acid at $1.94 \mu \mathrm{mol}$ have been proven to be effective in mobilising $\mathrm{Zn}$. Organic compounds can dissolve tightly bound forms of heavy metals which caused a decrease in the concentration of metals in any forms (Elkins and Nelson, 2002; Kos and Lestan, 2004). Zinc solubilisation activity relied on the concentration of organic acid. The concentration of malic acid at $0.047 \mu \mathrm{M}$ and $0.080 \mu \mathrm{M}$ of citric acid are directly proportional to the proton action produced which results in higher acidity and positive hydrogen ion that leads to higher $\mathrm{Zn}$ solubilisation (Krishnamurti et al., 1997). The results showed that the application of malic and citric acids highly affected the solubilisation of $\mathrm{Zn}$ from zinc sulfate both in the presence and in the absence of ZSB inoculation. Strength of $\mathrm{Zn}$ complexation with organic acids increased when organic acids become protonated (Lindsay, 1979; Impa and Johnson-Beebout, 2012). These weakening associations temporarily increase the free $\mathrm{Zn}$ in the solution, making it more available for plant uptake or for other competing reactions. However, at higher organic acid concentration, the plant growth decreased because an elevated level of $\mathrm{Zn}$ in plants may suppress the metabolism and translocation of reserve material in the plants (Gupta and Sinha, 2005).

The combination of ZSB with malic acid at $0.1 \mathrm{mM}$ has increased plant growth parameters (plant height, plant biomass and relative chlorophyll content), $\mathrm{Zn}$ uptake, $\mathrm{Zn}$ concentration and root volume. From the results, malic acid inoculated with ZSB showed a rapid increase in plant growth parameters with addition rates of organic acids compared to control. Plant growth, $\mathrm{Zn}$ uptake, $\mathrm{Zn}$ concentration and root volume increased when the availability of $\mathrm{Zn}$ became higher due to dissolution of $\mathrm{Zn}$ by organic acids. Zinc bioavailability to plants might be caused by secretion of root exudates which contains an organic acid (Hajiboland et al., 2005). However, a small amount of organic acids secreted by plants can be increased by introducing commercial organic acids like usual phytoremediation method. The method usually used for contaminated soil. But using suitable rates of organic acids, it might help for the increment of plant growth and $\mathrm{Zn}$ nutrition to the plant. Another factor that helped for the affected significant interaction on plant growth parameters is ZSB. Zincsolubilizing bacteria were found positive for IAA production, a phytohormone responsible for increasing the length of the root hairs which could promote better absorption of nutrients from the soil and lead to better $\mathrm{Zn}$ uptake by plants (Vaid et al., 2014). However, in this study, a higher concentration of organic acids than $1 \mathrm{mM}$ caused a reduction in plant growth parameters and root morphology. This is due to the increase in the concentration of organic acids as a longer chain of organic acid like citric acid caused increasing phytotoxicity to the plants' growth (Takijima, 1964). In rice, root elongation of rice seedlings had increased at 1 $\mathrm{mN}$ and $5 \mathrm{mN}$ but then decreased at $10 \mathrm{mN}$ acid concentrations due to the toxicity to the rice roots (Rao and Mikkelsen, 1977). Overall, there was a significant increase of $\mathrm{pH}$ during plant growth with ZSB inoculation because of their intrinsic system buffering potential by 
ZSB and insoluble zinc (Franz et al., 1991). Any addition of organic acids also had not affected the interaction between organic acids types and rates on bacterial population among the treatments during the planting period.

\section{Conclusion}

There was a significant effect of organic acids rate and $\mathrm{Zn}$ types on zinc solubilisation. Malic acid and citric acid showed a significant increase in $\mathrm{Zn}$ solubilisation when its concentration increased. Interaction of ZSB inoculation, organic acids and rates of organic acids was also significant for plant height, plant biomass, relative chlorophyll content, $\mathrm{Zn}$ uptake, $\mathrm{Zn}$ concentration, and root length and root volume. Among all, application of ZSB inoculation worked best with malic acid at $0.1 \mathrm{mM}$ concentration compared to control for plant growth and Zn uptake.

\section{Conflict of interest}

The authors declare no conflict of interest.

\section{Acknowledgements}

This research was supported by RACER/1/2019/ STG04/UITM//1 from the Malaysian Ministry of Higher Education (MOHE). The authors are grateful to the Faculty of Plantation and Agrotechnology, Universiti Teknologi Mara, Jasin Campus for generously providing research materials and facilities.

\section{References}

Amin, M.A., Uddin, M.A. and Hossain, M.A. (2004). Regeneration study of some Indica rice cultivars followed by Agrobacterium-Mediated transformation of highly regenerable cultivar BR-8. Journal of Biological Science, 4(2), 207-211. https:// doi.org/10.3923/jbs.2004.207.211

Duffner, A., Hoffland, E., Temminghoff, E.J.M. (2012). Bioavailability of zinc and phosphorus in calcareous soils as affected by citrate exudation. Plant Soil, 361, 165-175. https://doi.org/10.1007/s11104-012-1273-9

Ebrahimian, E. and Bybordi, A. (2012). Effect of salinity, salicylic acid, silicium and ascorbic acid on lipid peroxidation, antioxidant enzyme activity and fatty acid content of sunflower. African Journal of Agriculture Research, 7(25), 3685-3694. https:// doi.org/10.5897/AJAR12.492

Elkins, K.M. and Nelson, D.J. (2002). Spectroscopic approaches to the study of the interaction of aluminum with humic substances. Chemistry Revision, 228(2), 205-225. https://doi.org/10.1016/
S0010-8545(02)00040-1

Fasim, F., Ahmed, N., Parsons, R. and Gadd, G.M. (2002). Solubilization of zinc salts by a bacterium isolated from the air environment of a tannery. FEMS Microbiology Letter, 213(1), 1-6. https:// doi.org/10.1111/j.1574-6968.2002.tb11277.x

Fomina, M., Hillier, S., Charnock, J.M., Melville, K., Alexander, I.J. and Gadd, G.M. (2005). Role of oxalic acid overexcretion in transformations of toxic metal minerals by Beauveria caledonica. Application of Environmental Microbiology, 71(1), 371-381. https://doi.org/10.1128/AEM.71.1.371-381.2005

Goteti, P.K., Daniel, L., Emmanuel, A., Desai, S., Hassan, M. and Shaik, A. (2013). Prospective zinc solubilising bacteria for enhanced nutrient uptake and growth promotion in maize (Zea mays L.). International Journal of Microbiology, 2013, 7-18. https://doi.org/10.1155/2013/869697

Gupta, A.K and Sinha, S. (2006). Role of Brassica juncea (L) Czern. (var. Vaibhav) in the phytoextraction of Ni from soil amended with fly ash: selection of extractant for metal bioavailability. Journal of Hazardous Material, 136(2), 371-378. https://doi.org/10.1016/j.jhazmat.2005.12.025

Hajiboland, R., Yang, X.E., Römheld, V. and Neumann, G. (2005). Effect of bicarbonate on elongation and distribution of organic acids in root and root zone of Zn-efficient and Zn-inefficient rice (Oryza sativa L.) genotypes. Environment Experiment Botany, 54(2), 163-173.

https://doi.org/10.1016/ j.envexpbot.2004.07.001

Huang, L., Zhou, Q.X. and Zhang, Q.R. (2008). Removal effects of citric acid, oxalic acid and acetic acid on $\mathrm{Cd}, \mathrm{Pb}, \mathrm{Cu}$ and $\mathrm{Zn}$ in sewage sludge. Ying Yong Sheng Tai Xue Bao, 19(3), 641-646.

Impa, S.M. and Johnson-Beebout, S.E. (2012). Mitigating zinc deficiency and achieving high grain $\mathrm{Zn}$ in rice through integration of soil chemistry and plant physiology research. Plant Soil, 36, 172-178. https://doi.org/10.1007/s11104-012-1315-3

Lindsay, W.L. (1979). Chemical Equilibria in Soils. New York: John Wiley and Sons.

Khademi, Z., Jones, B. and Malakouti C.F. (2009). Organic acid mediated nutrient extraction efficiency in three calcareous soils. Australian Journal of Soil Research, 47(2), 213-220. https://doi.org/10.1071/ SR07179

Kos, B. and Lestan, D. (2004). Chelator induced phytoextraction and in situ soil washing of $\mathrm{Cu}$. Environmental Pollution, 132(2), 333-339. https:// doi.org/10.1016/j.envpol.2004.04.004

Krishnamurti, G.S.R., Cielsinki, G., Huang, P.M. and 
Van Pees, K.C.J. (1997). Kinectics of cadmium release from soils as influenced by organic acids: implication in cadmium availability. Journal of Environmental Quality, 26(1), 271-277. https:// doi.org/10.2134/jeq1997.00472425002600010038x

Labanowski, J., Monna, F., Bermond, A., Cambier, P., Fernandez, C., Lamy, I. and van Oort, F. (2008). Kinetic extractions to assess mobilization of $\mathrm{Zn}, \mathrm{Pb}$, $\mathrm{Cu}$, and $\mathrm{Cd}$ in a metal-contaminated soil: EDTA vs citrate. Enviromental Pollution, 152(3), 693-701. https://doi.org/10.1016/j.envpol.2007.06.054

Madhaiyan, M., Poonguzhali, S., Hari, K., Saravanan, V.S. and Sa, T. (2006). Influence of pesticides on the growth rate and plant-growth promoting traits of Gluconacetobacter diazotrophicus. Pesticide and Biochemical Physics, 84(2), 143-154. https:// doi.org/10.1016/j.pestbp.2005.06.004

Naher, U.A., Radziah, O., Zulkifli, S., Halimi, M.S. and Mohd, R.I. (2009). Growth enhancement and root colonization of rice seedlings by Rhizobium and Corynebacterium spp. International Journal of Agriculture Biology, 11(5), 586-590.

Robert, M.B.J. (1986). Role of biological and biochemical factors in soil mineral weathering. In Schnitzer, M. and Huang P.M. (Ed.), p. 453-495. Interactions of soil minerals with natural organics and microbes. Madison, WI: SSSA Special Publication. https://doi.org/10.2136/ sssaspecpub17.c12

Shakeel, M., Rais, A., Hassan, M.N. and Hafeez, F.Y. (2015). Root associated Bacillus sp. improves growth, yield and zinc translocation for Basmati rice (Oryza sativa) varieties. Frontier in Microbiology, 6 (780), 1-12. https://doi.org/10.3389/ fmicb.2015.01286

Simine, C.D.D. and Gadd, G.M. (1998). Solubilization of zinc phosphate by a strain of Pseudomonas fluorescens isolated from a forest soil. Biology in Fertility Soil, 28, 87-94. https://doi.org/10.1007/ s003740050467

Somasegaran, P. and Hoben, H.J. (1985). Methods in Legume-Rhizobium Technology. United States Agency for International Development (USAID)

Uren, N.C. (2000). The rhizosphere: biochemistry and organic substances at the soil-plant interface. CRC Press. 